\title{
E-PROCUREMENT USE IN THE NIGERIAN BUILDING INDUSTRY
}

\author{
Egidario B. Aduwo \\ Department of Architecture \\ Covenant University, Ota, Nigeria \\ Egidario.aduwo@covenantuniversity.edu.ng \\ Eziyi O. Ibem \\ Department of Architecture \\ Covenant University, Ota, Nigeria \\ Ibem.eziyi@covenantuniversity.edu.ng \\ Emmanuel A. Ayo-Vaughan \\ Department of Architecture \\ Bells University of Technology, Ota, Nigeria \\ kunlevaughan@gmail.com \\ Uwakonye O. Uwakonye \\ Department of Architecture \\ Covenant University, Ota, Nigeria \\ Obioha.uwakonye@covenantuniversity.edu.ng \\ James D. Owolabi \\ Department of Building Technology \\ Covenant University, Ota, Nigeria \\ james.owolabi@covenantuniversity.edu.ng
}

\begin{abstract}
Since the mid-1990s, the use of the electronic procurement aspect of electronic commerce (e-commerce) in the different business and industrial sectors has increased globally. However, the extent of its adoption in the Nigerian building industry is not clearly understood. This study investigated e-procurement use in the Nigerian building industry with a goal to improve the general understanding of the extent of its adoption in this country. The research involved a questionnaire survey of 213 respondents drawn from consulting and contracting firms, client organizations in the private sector, and government institutions conducted in Nigeria in 2015. The data were analyzed using descriptive statistics, Chi-square test, and multiple regression
\end{abstract}


analysis. The results show that the main users of e-procurement were quantity surveyors and construction/project managers in consulting firms. The most frequently used e-procurement technologies for advertising/announcing or receiving invitation to tender, exchanging project briefs and specifications, submitting/receiving tender/bids, and sourcing for materials and equipment were e-mails and websites. The type of organizations, top management support, and attitude towards current trends in e-procurement use in construction had the most significant influence on e-procurement adoption in the survey. The study concluded that only organisations with top management support and favourable attitudes towards the current trend in e-procurement use in construction, a good financial base, and information-technology-savvy staff would most likely adopt it in the Nigerian building industry.

Keywords: e-Procurement, e-Commerce, Building Industry, Internet, Survey, Nigeria

\section{INTRODUCTION}

Today, the rate at which individuals and organizations use different kinds of web-based information and communication technologies (ICTs) to carry out supply chain management activities is increasing. According to Berisha-Nmani, ${ }^{1}$ the use of information technology to support the execution of business activity engenders rapid and efficient communication, exchange of a large quantum of information, integration of multimedia documents, digitalization of procurement activities, establishment of direct online payments through the Internet, and creation of virtual organizations. The work by Kobayashi et al. ${ }^{2}$ supports the claim that the use of several aspects of electronic commerce (EC) is spreading across the globe. In fact, in the last two decades, interest among scholars and practitioners in the various aspects of e-commerce in the construction industry has been growing globally. ${ }^{3}$

One aspect of e-commerce that is gaining global acceptance in the construction industry is e-procurement. According to Bausa et al. ${ }^{4}$, e-procurement is the use of electronic communication technologies and transaction processes to buy services, goods, and works or conduct tendering for construction works. In construction, procurement is the process through which contracts relating to the provision of goods, services, and engineering and construction works or disposal services or any combination thereof are created, managed, and fulfilled. ${ }^{5}$ Therefore, e-procurement in the building industry can be described as the use of electronic communication technologies and transaction processes to support 
the execution of activities related to the creation, management, and fulfillment of building contracts.

The procurement of building projects involves several activities and processes that are usually project based and highly fragmented and require the input of different professionals, tradesmen, and service providers. ${ }^{6}$ These have given rise to several challenges in the creation, manipulation, storage, display, and exchange of vital information and data using paper-based techniques, tools, and processes. In order to overcome these challenges, several studies ${ }^{7,8}$ have indicated that firms in the construction industry have resorted to leveraging the Internet-based technologies, tools, and services to improve the levels of efficiency and productivity in the procurement of building works and services and infrastructure projects. Hence, several authors have investigated the use of e-procurement as an aspect of e-commerce in construction in several countries, including the USA, Canada, ${ }^{10}$ Australia, ${ }^{11}$ the UK, ${ }^{12,13,14,15}$ and South Africa. ${ }^{8}$ Others have examined the benefits, ${ }^{3,12,13}$ barriers, ${ }^{13,16,17}$ and factors influencing e-procurement adoption ${ }^{18,19}$ in construction supply chain management.

From the existing studies, we know that, apart from facilitating easy documentation and making exchange of information more accurate and efficient and at the lowest transaction cost ${ }^{20,21}$, e-procurement also ensures transparency and accountability in construction procurement. ${ }^{22}$ The existing studies $^{23,24}$ also reveal that several factors related to firms/organizations, the attributes of e-procurement technologies, and the environment in which adopters operate can influence the adoption of e-procurement. Among these factors, Rezgui et al. ${ }^{25}$ observed that organizational issues are among the key factors affecting the adoption of new technologies in the construction sector. Al-Moala and $\mathrm{Li}^{26}$ and Tran and Huang ${ }^{27}$ also corroborated this by noting that organisational issues play key roles in determining the extent, success, and impact of e-procurement use. This is because the decision to adopt new technologies and processes such as e-procurement is usually within the purview of organizations' top management, as explained by Ibem et al. ${ }^{24}$ and Eei et al. ${ }^{28}$

In spite of the growing body of knowledge on e-procurement use in the procurement of building and infrastructure projects, the extent of its adoption in the Nigerian building industry is not clearly understood. Although a study by Oyediran and Akintola ${ }^{29}$ examined e-tendering in construction, Aduwo et al. ${ }^{30}$ investigated the barriers to the uptake of e-procurement, and another by Ibem et al. ${ }^{24}$ explored the factors influencing e-procurement adoption in the Nigerian building industry, much is not known of the users of e-procurement and the different kinds of e-procurement tools and applications used in the Nigerian construction 
sector. Therefore, this research sought to examine the use of e-procurement in the Nigerian building industry with a goal of improving the understanding of the extent of its adoption in this country. The study was guided by three key research questions: (i) Who are the leading users of e-procurement in the Nigerian building industry? (ii) What are the different kinds of e-procurement technologies and tools used to execute e-notification, e-exchange, e-submission, e-sourcing and e-payment activities by organisations in the Nigerian building industry? and (iii)Which organizational factors contribute most to influencing the decision of organisations in the Nigerian building industry to adopt e-procurement?

This research is based on a questionnaire survey of 213 professional consultants, contractors, and private sector clients and government ministries/agencies and institutions in the Nigerian building industry. The focus was on building procurement activities involving e-notification, e-exchange, e-submission, e-sourcing, and e-payment. It contributes to the existing knowledge to improve understanding of the extent of e-procurement use in the Nigerian building industry. The study also provides fresh insight into the organizational-related factors that have the most influence on the decisions made by organisations in the Nigerian building industry to adopt e-procurement. Therefore, this study is considered an addition to the growing literature on e-procurement use in the construction industry.

\section{REVIEW OF RELATED LITERATURE}

In this section, the existing literature is reviewed regarding three main areas: theoretical background, e-procurement adoption in construction, and the factors influencing e-procurement adoption in construction.

\subsection{Theoretical Background}

Today, many theories have been developed to address the emerging issues associated with e-procurement adoption in the different industrial sectors. Williams and $\mathrm{Hardy}^{31}$ have explained that the adoption of technologies, applications, and services from the electronics and information systems industries in the construction sector is a form of technological innovation. Therefore, Zuo and $\mathrm{Seo}^{32}$ have described e-procurement in construction as a form of innovation adoption. The existing studies ${ }^{18,33,34}$ have shown that several issues associated with e-procurement adoption at both the individual and firm levels can be explained using theories related to innovation adoption, technology acceptance, reason action, and organisational management. Among the theories that have appeared in 
e-procurement adoption literature are Roger's Diffusion of Innovation (DOI) theory; the theory of reasoned action (TRA); the technological, organizational, and environmental (TOE) model; and the technology acceptance Model (TAM). However, the DOI theory and TOE model are considered relevant to this study because the focus is on e-procurement adoption at the organisational level.

From Roger's diffusion of innovation (DOI) theory ${ }^{35}$, we understand that a number of factors can influence the adoption of innovation. These include (i) the perceived attributes of e-procurement technologies (i.e. relative advantage, compatibility, complexity, trialability, and observability), (ii) the type of innovation decision in the adopting unit (optional, collective, authority), (iii) communication channels of diffusing e-procurement, (iv) the nature of the construction industry (e.g. its norms, degree of network, interconnectedness, etc.), and (v) the extent of change agents' promotion efforts. These imply that how organisations perceive the various attributes of e-procurement technology and its benefits and barriers to its uptake are among the key factors that influence the adoption of e-procurement by organisations in the construction sector.

The TOE framework developed by Tornatzky and Fleischer ${ }^{36}$ posits that a number of technological, organizational, and environmental factors influence the adoption of new technologies, processes, and ideas by organisations. The technological factors refer to the existing and emerging technologies within organisations. They include the quantity, quality, and characteristics of physical and social infrastructure such as practices, equipment, and technologies. The organizational factors are related to the internal context of organisations and may include among others the organisational culture, management structure, size of the organisation, scope of activities, and the human, material, and financial resource base of organizations. ${ }^{36}$ Tatum $^{37}$ proposed that the organisational factors that influence innovation adoption can be grouped into three categories: organisational structure, organisational culture, and key individuals. Based on these principles, Othman ${ }^{38}$ contended that the type of decision making, technological capabilities, organisational environment, slack resources that enable organisations to search for solutions, and external communication channels that increase awareness of innovations were some of the key organisational characteristics that can influence innovation adoption.

Although several studies ${ }^{24,33,35}$ have examined the factors that influence e-procurement adoption at the organisational level from diverse perspectives, none has specifically investigated the organisational factors influencing e-procurement adoption by organisations in the Nigerian building industry. 


\section{2. e-Procurement Adoption in Construction}

E-procurement is an aspect of e-commerce that involves activities and processes such as e-informing/e-notification/e-announcement, e-sourcing, e-tendering, e-reverse auctioning; e-ordering, e-payment, and others ${ }^{39,40,41,42}$ that enable organizations to engage in seamless and paperless procurement activities and processes ${ }^{33,43}$. According to Bakar et al. ${ }^{44}$, e-procurement activities include advertising and submitting tenders electronically, electronic sourcing and ordering via third parties, email communications related to buying and selling of goods and services, contract management, and the integration of procurement within financial and inventory systems. Following this submission, e-procurement technologies, tools and applications have been identified to include Internet-supported technologies, tools, and applications such as electronic data interchange (EDI), websites, portals, e-mail, GIS, GPS, RFID, Web 2.0, sensor networks, Building Information Modelling (BIM), enterprise resource planning (ERP), cloud computing, and software applications ${ }^{40,45}$.

Review of the published literature reveals that the existing works on e-procurement in construction can be classified into five broad categories. These are: (i) adoption studies, (ii) impact studies, (iii) studies on drivers and barriers, (iv) e-readiness, and (v) e-tendering ${ }^{8}$. A survey of the literature on adoption studies revealed that several authors have concentrated enormous research efforts on providing empirically based literature on e-procurement use in the construction sector. A summary of the studies identified is presented in Table 1.

Table 1. Summary of Studies on e-Procurement in Construction

\begin{tabular}{llll}
\hline Authors(year) & \multicolumn{1}{c}{ Methods } & Key findings & Limitations \\
\hline Issa et al. $^{9}$ & $\begin{array}{l}\text { Questionnaire } \\
\text { survey involving }\end{array}$ & $\begin{array}{l}\text { The respondents used } \\
\text { project management }\end{array}$ & $\begin{array}{l}\text { The study did not } \\
\text { identify the leading }\end{array}$ \\
& $\begin{array}{l}\text { 91 contractors in } \\
\text { the USA }\end{array}$ & $\begin{array}{l}\text { software packages, } \\
\text { Extranet/Intranet, the }\end{array}$ & $\begin{array}{l}\text { users of e-Procurement } \\
\text { and the organisational }\end{array}$ \\
& & $\begin{array}{l}\text { Internet, e-mail, fax EDI } \\
\text { for communication and } \\
\text { exchange of project } \\
\text { data and information }\end{array}$ & its adoption in that \\
& & & \\
& & & \\
& & & \\
& &
\end{tabular}


Table 1. Summary of Studies on e-Procurement in Construction (con.)

\begin{tabular}{|c|c|c|c|}
\hline Authors(year) & Methods & Key findings & Limitations \\
\hline Rankin et al. ${ }^{10}$ & $\begin{array}{l}\text { Questionnaire } \\
\text { survey involving } \\
226 \text { of } \\
\text { contractors, } \\
\text { suppliers and } \\
\text { their associates } \\
\text { in Canada }\end{array}$ & $\begin{array}{l}\text { Around } 94 \% \text { of the } \\
\text { participants were } \\
\text { involved in searching } \\
\text { and finding production } \\
\text { information } \\
\text { electronically, } 77 \% \\
\text { responded to bidding } \\
\text { opportunities; 70\% } \\
\text { transferred tender } \\
\text { information and } \\
\text { documents online. }\end{array}$ & $\begin{array}{l}\text { This studied was } \\
\text { limited to contractors } \\
\text { and suppliers, and did } \\
\text { not include } \\
\text { professionals. It did not } \\
\text { also investigate the } \\
\text { e-Procurement } \\
\text { technologies and tools } \\
\text { used and as well as the } \\
\text { organisational factors, } \\
\text { that influenced the } \\
\text { adoption of these } \\
\text { technologies. }\end{array}$ \\
\hline Zuo and $\mathrm{Seo}^{11}$ & $\begin{array}{l}\text { Questionnaire } \\
\text { survey involving } \\
127 \\
\text { construction } \\
\text { industry } \\
\text { stakeholders in } \\
\text { Australia }\end{array}$ & $\begin{array}{l}\text { All the respondents were } \\
\text { found to be using e-mail, } \\
\text { to execute online search; } \\
\text { exchange of CAD } \\
\text { drawings; place orders; } \\
\text { and receive bid invitation } \\
\text { and tenders. The } \\
\text { organisational factors } \\
\text { that had negative } \\
\text { influence on the adoption } \\
\text { of e-Procurement were } \\
\text { the lack of in-house } \\
\text { technical expertise and } \\
\text { personnel; organisational } \\
\text { culture; the lack of } \\
\text { integrated information } \\
\text { management system; and } \\
\text { fear of implementing a } \\
\text { business process change. }\end{array}$ & $\begin{array}{l}\text { The study did not } \\
\text { identify the main users } \\
\text { of e-Procurement } \\
\text { among the different } \\
\text { stakeholders sampled. } \\
\text { It did not also } \\
\text { investigate the aspect } \\
\text { of e-Payment }\end{array}$ \\
\hline Eadie et al. ${ }^{12}$ & $\begin{array}{l}\text { Web-based } \\
\text { survey involving } \\
70 \text { contracting } \\
\text { firms in Northern } \\
\text { Ireland }\end{array}$ & $\begin{array}{l}\text { The organisational } \\
\text { characteristics that } \\
\text { constituted barriers to the } \\
\text { use of these } \\
\text { e-Procurement systems } \\
\text { were company culture; } \\
\text { the lack of upper } \\
\text { management support; } \\
\text { lack of access to IT } \\
\text { infrastructure; and lack } \\
\text { of technical expertise, } \\
\text { e-procurement } \\
\text { knowledge / skilled } \\
\text { personnel. }\end{array}$ & $\begin{array}{l}\text { The study was limited } \\
\text { to contracting firms } \\
\text { and the use of } \\
\text { web-based systems and } \\
\text { CDR in the exchange } \\
\text { of tender information; } \\
\text { and thus, the finding is } \\
\text { not applicable to other } \\
\text { stakeholders in the } \\
\text { construction industry. }\end{array}$ \\
\hline
\end{tabular}


Table 1. Summary of Studies on e-Procurement in Construction (con.)

\begin{tabular}{|c|c|c|c|}
\hline Authors(year) & Methods & Key findings & Limitations \\
\hline Ahamed et al. ${ }^{46}$ & $\begin{array}{l}\text { A questionnaire } \\
\text { survey of } 50 \\
\text { professionals in } \\
\text { construction } \\
\text { industry of Sri } \\
\text { Lanka }\end{array}$ & $\begin{array}{l}\text { The reduction of paper work and } \\
\text { administrative and process cost } \\
\text { saving were identified as the key } \\
\text { drivers while, the lack of } \\
\text { policies, expertise, regulatory } \\
\text { bodies and legal challenges } \\
\text { were the key barriers to } \\
\text { e-Procurement adoption in } \\
\text { construction. }\end{array}$ & $\begin{array}{l}\text { The study focused } \\
\text { on } 50 \text { professionals } \\
\text { and did not include } \\
\text { other stakeholders } \\
\text { in the construction } \\
\text { sector of that } \\
\text { country to warrant } \\
\text { generalization of } \\
\text { these findings. The } \\
\text { study did not } \\
\text { identify the various } \\
\text { e-Procurement } \\
\text { technologies and } \\
\text { tools used. }\end{array}$ \\
\hline Eadie et al. ${ }^{15}$ & $\begin{array}{l}\text { Questionnaire } \\
\text { survey of } 483 \\
\text { participants } \\
\text { of the UK } \\
\text { construction } \\
\text { industry }\end{array}$ & $\begin{array}{l}\text { A majority of the procurement } \\
\text { activities was done } \\
\text { electronically on write-once CD. } \\
\text { E-Procurement adoption rate } \\
\text { across the UK construction } \\
\text { industry was found to be around } \\
27 \% \text {; while the private sector } \\
\text { was found to be lagging behind } \\
\text { the public sector in the } \\
\text { e-Procurement use in } \\
\text { construction. }\end{array}$ & $\begin{array}{l}\text { The study identified } \\
\text { the type of } \\
\text { organization as the } \\
\text { only organizational } \\
\text { factor that } \\
\text { influenced the } \\
\text { adoption of } \\
\text { e-Procurement in } \\
\text { construction. }\end{array}$ \\
\hline Isikdag et al. $^{16}$ & $\begin{array}{l}\text { Web-based } \\
\text { questionnaire } \\
\text { survey } \\
\text { involving } 200 \\
\text { respondents in } \\
\text { the Turkish } \\
\text { architecture } \\
\text { engineering } \\
\text { and } \\
\text { construction } \\
\text { industry }\end{array}$ & $\begin{array}{l}\text { The lack of upper management } \\
\text { support, technical expertise and } \\
\text { lack of training regarding the } \\
\text { implementation and use of } \\
\text { e-Commerce systems were the } \\
\text { organisational related factors } \\
\text { that constituted barriers to } \\
\text { e-Procurement adoption in that } \\
\text { country }\end{array}$ & $\begin{array}{l}\text { This study was } \\
\text { limited to the } \\
\text { barriers to } \\
\text { e-Procurement } \\
\text { adoption as it did } \\
\text { not identify the } \\
\text { e-Procurement } \\
\text { technologies used }\end{array}$ \\
\hline Huang et al. ${ }^{47}$ & $\begin{array}{l}\text { Questionnaire } \\
\text { survey of } 112 \\
\text { construction } \\
\text { businesses in } \\
\text { Vietnam. }\end{array}$ & $\begin{array}{l}\text { Government roles in providing } \\
\text { leadership, legal and regulatory } \\
\text { infrastructure, information and } \\
\text { technology infrastructure (ITI), } \\
\text { and socio-economic and } \\
\text { knowledge infrastructure were } \\
\text { identified to have had a } \\
\text { significant influence on a } \\
\text { decision of initial adoption of } \\
\text { e-Procurement in construction } \\
\text { enterprises. }\end{array}$ & $\begin{array}{l}\text { The study did not } \\
\text { investigate the } \\
\text { actual users of } \\
\text { e-Procurement and } \\
\text { the specific types of } \\
\text { e-Procurement } \\
\text { technologies and/or } \\
\text { tools used. }\end{array}$ \\
\hline
\end{tabular}




\begin{tabular}{|c|c|c|c|}
\hline Authors(year) & Methods & Key findings & Limitations \\
\hline Zunk et al. $^{48}$ & $\begin{array}{l}\text { Questionnaire } \\
\text { survey of } 100 \\
\text { construction } \\
\text { firms in } \\
\text { Australia }\end{array}$ & $\begin{array}{l}\text { The respondents used } \\
\text { special ordering software } \\
\text { with e-mail, supplier's } \\
\text { online shops and special } \\
\text { ordering software in } \\
\text { combination with an EDI } \\
\text { interface. It was also } \\
\text { observed that the potential } \\
\text { for cost reduction was not } \\
\text { fully exploited }\end{array}$ & $\begin{array}{l}\text { The study was limited } \\
\text { to construction firms; } \\
\text { and it did not identify } \\
\text { the organisational } \\
\text { factors that influenced } \\
\text { the adoption of } \\
\text { e-Procurements by the } \\
\text { contractors sampled. }\end{array}$ \\
\hline $\begin{array}{l}\text { Ibem and } \\
\text { Laryea }^{8}\end{array}$ & $\begin{array}{l}\text { Online } \\
\text { questionnaire } \\
\text { survey } \\
\text { involving } 603 \\
\text { stakeholders in } \\
\text { the South } \\
\text { African } \\
\text { construction } \\
\text { industry. }\end{array}$ & $\begin{array}{l}\text { The three most widely } \\
\text { used e-Procurement } \\
\text { technologies were e-mail, } \\
\text { websites and portals, } \\
\text { which were used for } \\
\text { communication, exchange } \\
\text { of bill of quantities, CAD } \\
\text { drawings and project } \\
\text { specifications. }\end{array}$ & $\begin{array}{l}\text { The study did not } \\
\text { identify the leading } \\
\text { adopters of } \\
\text { e-Procurement and the } \\
\text { organisational factors } \\
\text { that have significant } \\
\text { influence on its } \\
\text { adoption. }\end{array}$ \\
\hline $\begin{array}{l}\text { Sholanke and } \\
\text { Fapohunda }^{49}\end{array}$ & $\begin{array}{l}\text { Questionnaire } \\
\text { survey of } 93 \\
\text { respondents in } \\
\text { the South } \\
\text { African } \\
\text { construction } \\
\text { industry }\end{array}$ & $\begin{array}{l}\text { The factors that } \\
\text { constituted barriers to the } \\
\text { adoption of e-Procurement } \\
\text { in sourcing construction } \\
\text { materials were the lack of } \\
\text { awareness, resistance to } \\
\text { change, (c) high cost of } \\
\text { installation and operation } \\
\text { and Internet fraud }\end{array}$ & $\begin{array}{l}\text { The study focused only } \\
\text { on the use of } \\
\text { e-Procurement in the } \\
\text { procurement of } \\
\text { construction materials; } \\
\text { and thus neglecting } \\
\text { other uses of } \\
\text { e-Procurement in } \\
\text { construction. In } \\
\text { addition, the study did } \\
\text { not identify the } \\
\text { specific type of } \\
\text { e-Procurement } \\
\text { technologies and } \\
\text { application used. }\end{array}$ \\
\hline
\end{tabular}

Source: Compiled by the authors

From the studies presented in Table 1, it is evident that, among different countries, the use of e-procurement in construction has been growing, and different types of e-procurement technologies, systems, applications, and tools are being used to carry out a wide range of construction procurement activities. Notably, most of the existing studies view the construction industry as a homogenous entity without acknowledging the different components such as building, road, power, and others. Consequently, less attention has been given to investigating e-procurement adoption in the different components of the construction sector, such as the building industry, especially in a developing country like 
Nigeria. This calls for more research in this area for adequate understanding of the current state of affairs when it comes to e-procurement use.

\subsection{Factors Influencing e-Procurement Adoption in Construction}

The published literature is replete with findings regarding the organisational and human factors influencing e-procurement adoption in the different business and industrial sectors. For example, Al-Moala and $\mathrm{Li}^{26}$ investigated the organisational issues associated with e-procurement adoption by public sector organizations in the United Arab Emirates. The authors reported that e-procurement adoption by government institutions in that country was influenced by planning, policy development change management strategies, human resource management, and staff education and training. $\mathrm{Ng}^{50}$ also investigated e-commerce adoption in the Australian agricultural sector. That study identified the availability of financial, human, and physical resources; the target market and market scope; organizations' technological infrastructures and knowledge; the types of business strategy adopted by the organisations; organizational structure and culture; and the organizations' understanding of the various types of e-commerce models as the key organisational factors influencing the adoption of e-commerce in that sector. Based on the findings of the literature review, Patel et al. ${ }^{51}$ observed that the organisational factors influencing e-procurement adoption in the different business and industrial sectors are basically budgetary allocation for e-procurement adoption, top management support (i.e. organization's policy on ICTs use), and the employees' skills and knowledge of e-procurement technologies and tools.

In the construction sector, Teo et al. ${ }^{18}$ examined the factors that influenced e-procurement adoption among 141 companies, including architecture/engineering/construction firms in Singapore. The authors found that, among other factors, the firm size, top management support, perceived indirect benefits, and business partner influence were positively and significantly associated with e-procurement adoption by firms in that country. That study, however, did not identify the main users of e-procurement in that country. The study by Eadie et al. ${ }^{15}$ cited in Table 1 also found that the size of organisations, their expenditure on procurement, and the sector they belong to (i.e. private or private) were correlates of e-procurement use in construction. Further, Daud et al. ${ }^{18}$ reported that the intention to use was the key factor that influenced e-procurement adoption among 178 contractors in Malaysia. Ibem et al. ${ }^{24}$ also investigated the factors influencing e-procurement among 213 professional consulting firms, contractors, client organizations, and government establishments in the 
Nigerian building industry. That study noted that the most important factors influencing the adoption of e-procurement in the order of importance were the benefits of e-procurement in ensuring efficient project delivery process, removing geographic impediments, and enhancing effective communication by the participants in the building procurement process. That study, however, did not capture the various e-procurement systems and applications used in the Nigerian building industry.

From the foregoing evidence, it is also apparent that previous studies have examined the various organizational factors that can influence the decision to adopt e-procurement in the different business and industrial sectors. Hashim et al. ${ }^{6}$, however, observed that there has been limited research into the organisational factors affecting the adoption of e-procurement by stakeholders within the construction sector of developing countries. In fact, evidence from the review of existing literature suggests that not much research has been done to explore the organizational factors influencing the decision to adopt e-procurement in the building industry, particularly in a developing country like Nigeria. Therefore, this study was designed to bridge this research gap.

\section{RESEARCH METHODS}

This paper draws on a larger research project designed to investigate the extent of e-procurement use in the Nigerian construction industry. The research followed a quantitative research approach with a questionnaire survey as the primary data collection strategy used. Previous studies ${ }^{9,10,12,15}$ used similar approaches. The questionnaire used was designed by the researchers and posed questions regarding the following aspects: the profiles of the respondents and their organizations, the different e-procurement technologies and tools used in supporting the execution of the aforementioned construction procurement activities, and factors influencing the decision of the firms to adopt e-procurement.

In identifying the actual users of e-procurement, the respondents were asked to indicate whether their organisations have participated in a project that involved the use of e-procurement by clicking "Yes" or "No." Regarding the e-procurement technologies used, participants in this research were also requested to indicate the frequency of use of the different e-procurement technologies, tools, and applications to support the execution of building procurement activities based on 3-Likert-type scale. Responses ranged from $1=$ "Never used," $2=$ "Sometimes," and 3= "Always." The five procurement activities investigated in this study were (i) announcing/notification/receiving of tender opportunities, (ii) exchange of 
project briefs and/or specifications, (iii) submitting/receiving tender/proposals/expression of interest (iv)sourcing for materials and equipment, and (v) receiving/paying for materials, equipment, and/or services related to building procurement. The choice of a 3-Likert type scale was made firstly because this aspect of the questionnaire was not designed using agreement, quality, satisfaction, importance, impact, or difficulty scale, which is usually based on 5- or 7-point Likert-type scales, rather than a frequency scale, which measures the extent to which participants in the research use the identified e-procurement technologies, tools, and application to support the execution of the selected construction procurement activities. Secondly, it was informed by the need to be as specific as possible and to ensure that none of the options overlaps with another. Thirdly, it was also based on the recognition of the fact that the fewer the options available, the faster the participants can complete the survey. On the other hand, the data on organisational factors that influence e-procurement use, such as the availability of IT staff and top management support, were collected using scales that measure the level of importance by assigning numerical values. These scales included $1=$ "Not Important," $2=$ "Least Important," 3= "Undecided," 4 = "Important," and 5 = "Most Important to each of the options, as shown in the questionnaire in Appendix A. This means that these variables were measured on an ordinal scale. Similarly, the data on organisational characteristics such as the type of organization use the following coding: " 1 " for consulting firm contractor, " 2 " for client organization, " 3 " for government ministry/parasatals/institution, and "4" for others, as shown in the questionnaire in Appendix A. This means that they were coded as nominal variables.

Prior to the main survey, a pilot survey was conducted in Lagos in April 2015, and the focus was on architectural and quantity surveying firms. Feedback from the pilot survey was useful in fine tuning the questions in the questionnaire before the main survey. The authors and trained research assistants carried out the main survey between June and November 2015 in Nigeria. The stakeholders in the Nigerian building industry sampled were from architectural, building, and quantity surveying firms. The data were extracted from the architectural firms during the Architects' Colloquium, which took place in Abuja in June 2015, while the Annual Builders' National Conference and Meeting held at the University of Ibadan in August 2015 served as the avenue for obtaining information from builders and contracting firms. Similarly, the quantity surveying firms who participated in the research were sampled at the Federal University of Technology, Akure (FUTA), in November 2015 during the Annual QS Research Conference. During each of these conferences and meetings, participants were randomly 
selected for the administration of the questionnaire by hand. In addition, some client organizations in the public (government ministries/parasatals) and private sectors (e.g. oil and gas, telecommunication, manufacturing) and building construction companies in Lagos, Abuja, and Port Harcourt were purposively selected to participate in the survey. Of the 500 questionnaires administered, 213 valid questionnaires representing around $43 \%$ of the total questionnaire administered were retrieved. This indicates a response rate of about $43 \%$. Previous studies ${ }^{10,18}$ had similar response rate.

The Statistical Package of the Social Sciences (SPSS) Version 20 was used in progressing and analysing the data. The data were analysed using descriptive statistics, Chi-square test, and multiple regression analysis. Specifically, descriptive statistics were used to compute frequency and percentages of the variables investigated, while the Chi-square test was used to investigate whether the observed pattern in the use of e-procurement among professional consultants in this survey is statistically significant.

The third analysis was the Categorical Regression (CATREG) analysis, which is a variant multiple regression analysis used in the analysis of the data set comprising a mixture of nominal, ordinal, and numerical data. CATREG has an advantage over the standard multiple regression analysis in that it transforms and standardises non-numerical data into numerical data prior to estimation, thus producing only standardized coefficient estimates, as explained by Shrestha. ${ }^{53}$ This analysis was used to address the third research question of this study, which relates to the identification of the organisational factors that contribute mostly to influencing the decision by organisations in the Nigerian building industry to adopt e-procurement. In investigating this, we set as the dependent variable, "Participation in a Project involving the use of e-Procurement by the organizations," while the following factors were set as the independent variables: (i) type of organization, (ii) sector of procurement experience, (iii) age of organization, (iv) availability of IT staff in the organization, (v) the number of offices the organization has in Nigeria, (vi) size of the organization, (vii) top management support resulting on the perceived benefits of e-procurement use, (viii) the desire of the organisations to align with global trends in e-procurement use, (ix) the geographic spread of the organizations' business activities, (x) scope of organization's operational activities, (xi) and the financial base of the organisations. 


\section{RESULTS}

The profile of 213 valid respondents was summarized in Table 2.

Table 2. Profile of the Respondents and their Organizations

\begin{tabular}{lcc}
\hline Background Information & n & \% \\
\hline Professional Background & & \\
Architect & 75 & 35.2 \\
Builder & 47 & 22.1 \\
Engineer & 9 & 4.2 \\
Construction/ Project manager & 20 & 9.4 \\
Quantity Surveyor (QS) & 56 & 26.3 \\
Procurement/Supply chain manager & 6 & 1.9 \\
Type of organization & & \\
Consulting firms & 72 & 33.8 \\
Contractors & 45 & 21.1 \\
Private sector client organizations & 21 & 9.9 \\
Government Ministry and Parasatals & 75 & 35.2 \\
Sector of procurement experience & & \\
Public sector only & 36 & 16.9 \\
Private sector only & 52 & 24.4 \\
Both public and private sector & 125 & 58.7 \\
Staff Strength & & \\
Below 20 employees & 94 & 44.1 \\
Between (20 and 50) employees & 45 & 21.1 \\
Between 51 and 100) employees & 14 & 6.6 \\
Over 100 employees & 56 & 26.3 \\
No Response & 4 & 1.9 \\
Age of Organization & & \\
Less than 5 years & 31 & 14.6 \\
Between (6-10) years & 52 & 24.4 \\
More than 10 years & 126 & 59.2 \\
No Response & 4 & 1.9 \\
Number of offices in Nigeria & & \\
One office & 84 & 39.4 \\
Two offices & 52 & 24.4 \\
Three offices & 17 & 8.0 \\
More than three offices & 42 & 19.7 \\
No Response & 18 & 8.5 \\
Range of annual turnover in Naira & & \\
Less than 100 million & 40 & 10.7 \\
100-500 million & & \\
600 million-1billion & & \\
Over 1 billion & & 18.8 \\
No Response & & \\
\hline
\end{tabular}

Table 2 shows that the highest proportion (35.2\%) of those who participated in the survey were architects, followed by $26.3 \%$ who were 
quantity surveyors. In addition, around $35 \%$ of the respondents were employed in government ministries or parasatals (i.e. agencies under government ministries), while $34 \%$ and $21 \%$ worked in consulting and contracting firms, respectively. Table 2 also reveals that most (59\%) of the organizations from where the participants were drawn were over ten years old, $54 \%$ of them had staff size of over 20 persons, while more than one-half had at least two offices in Nigeria. Similarly, the procurement experiences of the organizations were in both the public and private sectors of the Nigerian economy. This result suggests that the key organizations and professionals in the Nigerian building industry participated in this research; hence, the findings can be generalised in the context of the Nigerian building industry.

\subsection{Users of e-Procurement in the Nigerian Building Industry}

The result on the actual adopters of e-procurement in the Nigerian building industry shows that around 110 (52\%) of the respondents said they have not participated in a project that involved the use of e-procurement, 84 $(39.4 \%)$ claimed that they have participated in projects that involved the use of e-procurement, and 19 (9\%) provided no response on this item. Figure 1 is the distribution of the users of e-procurement according to their professional roles in the Nigerian building industry. Examination of the result (Figure 1) reveals that around 55\% of the quantity surveyors and construction/project managers sampled had participated in projects involving the use of e-procurement, followed by $44 \%$ and $32 \%$ of the engineers and architects, respectively. The least proportions of users were the builders and procurement/supply chain managers. The results presented in Figure 1 also shows that there is a difference between those who have participated in projects that involved the use of e-procurement and those who have not in terms of their distribution among the six professional groups sampled in the survey.

To examine whether the difference observed in the distribution of users of e-procurement in the survey is statistically significant, a Chi-square test of independence was conducted, and the result produced large Chi-square statistics $(87.36)$ at a significant level $(p<0.001)$. This indicates that it is very unlikely that participation in projects involving the use of e-procurement is independent of the professional background of the respondents. Therefore, the observed pattern in the use of e-procurement among the professional consultants in this survey is statistically significant. This suggests that there is a relationship between professional background and e-procurement use in the Nigerian building industry. 


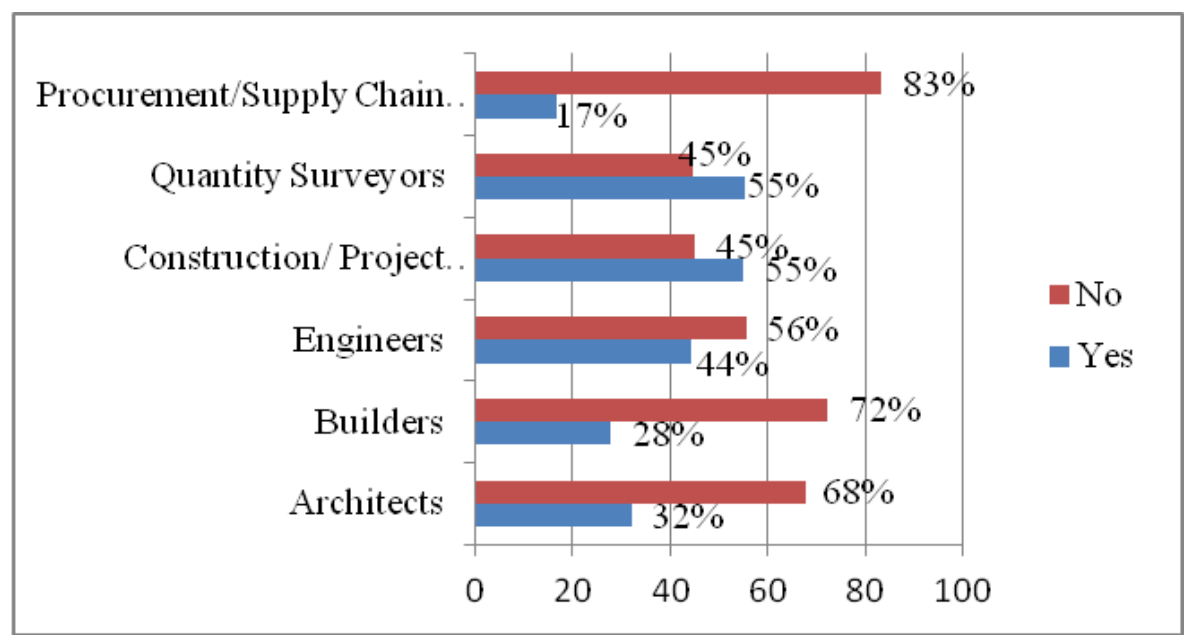

Figure 1. Distribution User of e-Procurement among Professional Consultants

Figure 2 shows that distribution of the users of e-procurement across the four groups of organizations from which respondents were drawn. It is evident from the results in Figure 2 that the highest percentages of users of e-procurement were consulting firms, followed by contractors and government and client organizations in the private sector.

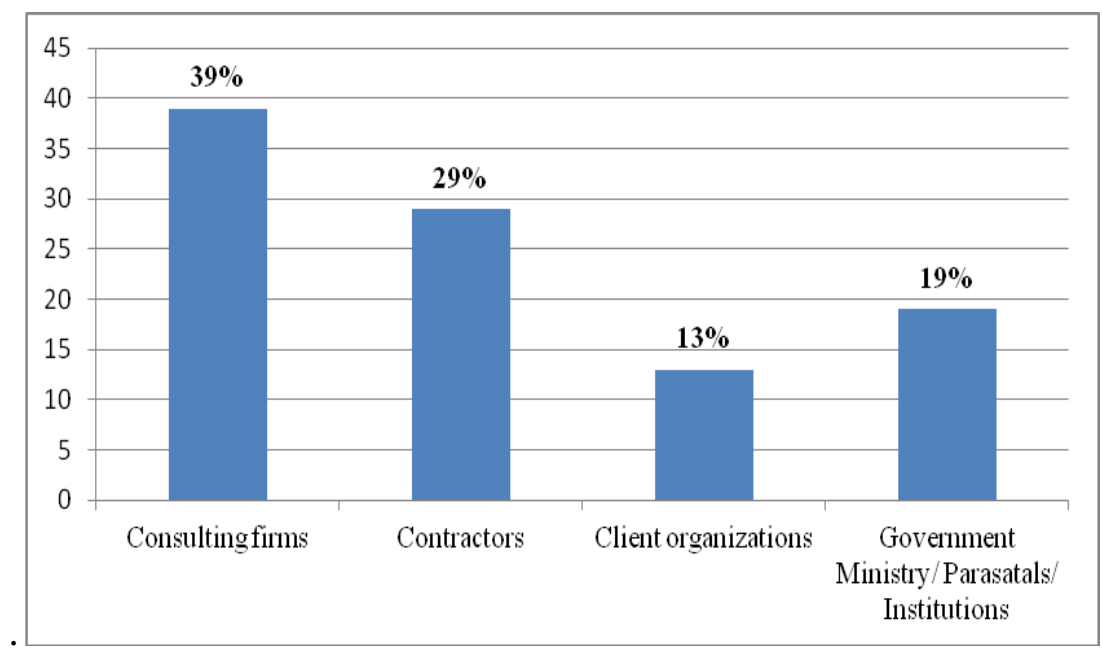

Figure 2. Users of E-Procurement in the Four Organizations

The result also revealed that, amongst the organisations using e-procurement, around $25(29.7 \%)$ of them indicated that their procurement experience is mainly in the private sector, $12(14.3 \%)$ said their experience is mainly in the public sector, and $47(56 \%)$ indicated that their building 
procurement experience is in the both the public and private sectors. This means that a greater percentage of the organisations had their procurement experience in both the private and public sectors. This result suggests that the leading users of e-procurement are consulting firms, followed by contractors, and the private sector takes the lead in the use of e-procurement in the Nigerian building industry.

\section{2. e-Procurement Technologies and Tools Used}

As noted earlier, the study also investigated the different e-procurement technologies, tools, and applications used to support the execution of the aforementioned five building procurement activities by those who claimed to be using e-procurement in the survey. The result is as presented in Table 3. It is evident from the result (Table 3) that a majority of those who used e-procurement to announce or receive information on the availability of tender opportunities as well as exchange project briefs/specifications mostly used e-mails and static websites to support the execution of these activities. The result also indicates that, in submitting/receiving tender/ proposals/expression of interest, the most commonly used technology or application was email, followed by static websites. It is also evident that emails, websites, and e-catalogues were the most frequently used applications when sourcing for building materials and equipment, while electronic transfer is the most frequently used method of payment for goods/materials and services in the procurement of building projects.

\subsection{Organizational Factors Influencing the Decision to Adopt e-Procurement}

The organizational factors that influenced the decision by the organisations whose employees identified to be using e-procurement were investigated using Categorical Regression (CATREG) analysis. The results of this analysis are presented in Table 4. From this result (Table 4), it is evident that, of the eleven independent variables investigated, five predicted the decision to adopt e-procurement among the firms sampled with $\mathrm{F}(33$, $212.00)=19.500, p<0.005$. The $\mathrm{R}^{2}$ value $(0.564)$ of the model indicates that the regression model explains around $56.4 \%$ of the variance in the decision to adopt e-procurement. 
Table 3. e-Procurement Technologies, Tools and Application Used

\begin{tabular}{|c|c|c|c|}
\hline \multirow[b]{2}{*}{$\begin{array}{l}\text { Procurement Activities } \\
\text { and Technologies }\end{array}$} & \multirow[b]{2}{*}{$\begin{array}{c}\text { Always } \\
n(\%)\end{array}$} & \multicolumn{2}{|c|}{ Frequency of use } \\
\hline & & $\begin{array}{c}\text { Sometimes } \\
n(\%)\end{array}$ & $\begin{array}{l}\text { Never used } \\
\quad n(\%)\end{array}$ \\
\hline \multicolumn{4}{|c|}{ Announce/Receive Information on Tender Opportunities } \\
\hline Websites & $48(57.0)$ & $24(29.0)$ & $12(14.3)$ \\
\hline Project Portals & $20(23.8)$ & $30(35.7)$ & $34(40.5)$ \\
\hline E-mail & $60(71.4)$ & $17(20.2)$ & $7(8.3)$ \\
\hline $\begin{array}{l}\text { Web } 2.0 \text { Technology-based } \\
\text { system }\end{array}$ & $6(7.2)$ & $20(23.8)$ & $58(69.0)$ \\
\hline \multicolumn{4}{|c|}{ Exchange Project Briefs and Specifications from Clients } \\
\hline E-Mail & $50(59.5)$ & $21(25.0)$ & $13(15.5)$ \\
\hline Websites & $45(54.0)$ & $30(35.0)$ & $9(11)$ \\
\hline Internet supported faxing & $12(14.3)$ & $29(34.5)$ & $43(51.2)$ \\
\hline Voice on Internet Protocol & $6(7.1)$ & $30(35.7)$ & $48(57.2)$ \\
\hline \multicolumn{4}{|c|}{ Submit/Receive of Tenders/Proposals/Expression of Interest } \\
\hline Cloud-based applications & $11(13.1)$ & $25(29.8)$ & $48(57.1)$ \\
\hline Project Portal & $9(10.7)$ & $30(36.0)$ & $45(54.0)$ \\
\hline E-Mail & $50(59.5)$ & $19(22.6)$ & $15(17.9)$ \\
\hline $\begin{array}{l}\text { Internet supported systems, } \\
\text { software applications }\end{array}$ & $28(33.3)$ & $29(34.5)$ & $27(32.1)$ \\
\hline $\mathrm{CD} / \mathrm{CDROM}$ & $18(21.4)$ & $28(33.3)$ & $38(45.2)$ \\
\hline \multicolumn{4}{|c|}{ Source for Materials \& Equipment } \\
\hline E-Mail & $70(83.3)$ & $9(10.7)$ & $5(6.0)$ \\
\hline e-Market Place & $20(23.8)$ & $25(29.8)$ & $39(46.4)$ \\
\hline $\begin{array}{l}\text { Internet based geographic } \\
\text { information system (GIS) }\end{array}$ & $23(27.4)$ & $29(34.5)$ & $32(38.1)$ \\
\hline Websites & $35(41.7)$ & $24(28.8)$ & $25(29.8)$ \\
\hline e-Catalogues & $26(31.0)$ & $20(23.8)$ & $38(45.2)$ \\
\hline $\begin{array}{l}\text { Electronic Data Interchange } \\
\text { (EDI) }\end{array}$ & $14(16.7)$ & $20(23.8)$ & $50(59.5)$ \\
\hline \multicolumn{4}{|c|}{ Make/Receive Payment for Materials, Goods and Services } \\
\hline Credit Card & $29(34.5)$ & $27(32.1)$ & $28(33.3)$ \\
\hline Electronic transfer & $44(52.4)$ & $20(23.8)$ & $20(23.8)$ \\
\hline
\end{tabular}


Table 4. Coefficients of the Regression Analysis

\begin{tabular}{|c|c|c|c|c|c|}
\hline \multicolumn{6}{|c|}{ Coefficients } \\
\hline & \multicolumn{2}{|c|}{ Standardized Coefficients } & \multirow{2}{*}{ df } & \multirow[t]{2}{*}{$\mathrm{F}$} & \multirow{2}{*}{ Sig. } \\
\hline & Beta & $\begin{array}{l}\text { Bootstrap } \\
\text { (1000) Estimate } \\
\text { of Std. Error }\end{array}$ & & & \\
\hline Category of organization* & 0.308 & 0.074 & 4 & 17.381 & 0.000 \\
\hline Sector of procurement experience & 0.043 & 0.052 & 2 & 0.687 & 0.504 \\
\hline Age of organisation & 0.063 & 0.059 & 2 & 1.129 & 0.326 \\
\hline Number of offices in Nigeria & 0.081 & 0.060 & 3 & 1.834 & 0.143 \\
\hline Financial base of organization* & 0.235 & 0.073 & 4 & 10.409 & 0.000 \\
\hline $\begin{array}{l}\text { Availability of IT manpower in } \\
\text { the organization* }\end{array}$ & -0.164 & 0.084 & 2 & 3.770 & 0.025 \\
\hline $\begin{array}{l}\text { The desire to align with global } \\
\text { trends in e- Procurement use* }\end{array}$ & -0.260 & 0.103 & 3 & 6.407 & 0.000 \\
\hline $\begin{array}{l}\text { Geographical spread of the } \\
\text { organization's business activities }\end{array}$ & 0.018 & 0.163 & 2 & 0.012 & 0.988 \\
\hline $\begin{array}{l}\text { Scope of organization's } \\
\text { operational activities }\end{array}$ & 0.116 & 0.200 & 2 & 0.338 & 0.713 \\
\hline Top management support* & 0.274 & 0.152 & 3 & 1.312 & 0.000 \\
\hline Size of organization & -0.154 & 0.157 & 3 & 1.082 & 0.358 \\
\hline
\end{tabular}

*Dependent Variable: Participation in Projects involving the use of e-Procurement *significant predictors

Table 4 is a display of the coefficients obtained in the regression analysis. From the $p$ (Sig)-values, it is evident that the following factors were the significant predictors of the decision by the organizations to adopt e-procurement in the procurement of building projects: type of organization, financial base, availability of IT staff, oragnisation's desire to align with global trends in e-procurement use, and top management support. Also the beta values show that "the category (type) of the organization" with a beta value of 0.308 makes the strongest unique contribution to explaining the decision to adopt e-procurement. This is followed by top management support $(\beta=0.274)$, an organisation's desire to align with global trends in e-procurement use $(\beta=0.260)$, financial base of the organization $(\beta=0.235)$, and availability of IT staff in the organisation $(\beta=0.164)$, respectively.

\section{DISCUSSION AND IMPLICATIONS OF FINDINGS}

From the results presented in the preceding section, three key issues related to the research questions of the study are identified for further discussion. First, regarding the leading users of e-procurement in the Nigerian building industry, this study revealed that consulting firms were the leading users of e-procurement in Nigeria, followed by contractors and government ministries, parasatals, and institutions. This finding suggests 
that private sector organizations are using e-procurement more than their public sector counterparts are. Thus, one can infer that the private sector in the Nigerian building industry is taking the lead when it comes to e-procurement adoption. This result seems to be similar to the situation in the South African construction industry, where Ibem and Laryea ${ }^{8}$ reported that the private sector was taking the lead in e-procurement use. The socio-economic and technological similarities between Nigeria and South Africa may partly explain this similarity in the results. However, this result contradicts the finding by Eadie et al. ${ }^{15}$ indicating that the public sector represented the leading sector in the adoption of e-procurement in the UK construction industry. The leading role of governments in driving change in developed countries such as the UK, as explained by Eadie et al. ${ }^{12,15}$, may be the reason why the public sector lead the e-procurement adoption in the UK construction industry. In the same vein, our survey data reveals that quantity surveyors and construction/project managers were the leading adopters of e-procurement in the Nigerian building industry. The engineers and architects follow the surveyors and construction/project managers, respectively. This result did not come as a surprise, because the previous study by Oyediran and Akintola ${ }^{29}$ revealed that more quantity surveyors than any other professionals in the Nigerian construction industry have participated in e-tendering. Indeed, the study by Eadie et al. ${ }^{14}$ underscored the prominent and leading roles of quantity surveyors in the adoption of e-procurement in the UK. Hence, their views on the drivers and barriers to e-procurement in the UK construction organizations were sought.

This finding means that, unlike in the UK, where the public sector took the lead in e-procurement adoption in the construction sector, in countries like Nigeria and South Africa, the reverse is the case. This presents the implication that the role of government may be lacking in providing leadership, legal and regulatory framework, and information and technology infrastructure to engender critical mass uptake of e-procurement, as identified by Haung et al. ${ }^{47}$, and that this might persist for a longer time if adequate steps are not taken to address this situation. This means that it would take a longer time for a developing country like Nigeria to have a significant improvement in the level of uptake of e-procurement in the delivery of building projects if government continues to shy away from its responsibility in providing the right leadership in the automation of the construction procurement activities and processes in line with international best practices.

Second, regarding the different kinds of e-procurement technologies, tools, and applications used to execute the five aspects of procurement tasks investigated in this study, the study found extensive use of e-mails and static 
websites in announcing or receiving information on the availability of tender opportunities and exchanging project briefs/specifications. Interestingly, that study by Ibem and Laryea ${ }^{8}$ also reported that, in the South African construction industry, there was extensive use of emails and websites to support the execution of procurement tasks such as announcing or receiving information on the availability of tender opportunities and exchanging project briefs/specifications. The previous studies in the USA by Issa et al. ${ }^{9}$, the $\mathrm{UK}^{12,15}$, and Australia by Zuo and Seo ${ }^{11}$ also reported the extensive use of web-based applications, such as emails and static websites in the execution of these activities. The choice of these e-procurement technologies may not be unconnected with the assertion by Ibem and Laryea ${ }^{8}$ that e-mails and websites facilitate the speedy exchange of data and information by participants in construction projects. Our survey data also indicated the use of e-mails and websites when sourcing for materials and equipment. Again, previous studies in the $\mathrm{UK}^{12,15}$, the $\mathrm{USA}^{9}$, and Austarlia ${ }^{48}$ also found similar practices in these countries' construction sector. Specifically, Zunk ${ }^{48}$ reported that Australian construction firms were using special ordering software with e-mail to source and place orders for construction materials and equipment.

The use of electronic transfer for payment for procurement-related goods and services was also observed in the survey. Although this finding appears to contradict the earlier work by Oyediran and Akintola ${ }^{29}$, indicating that there was relatively low usage of digital technology in making and receiving payments for construction-related activities in Nigeria, the findings of the current study however appear to be consistent with that by Zunk et al. ${ }^{48}$, indicating that, in Australia, construction firms used special ordering software with e-mail, suppliers' online shops (e-Marketplace) and special ordering software to search, place orders, and pay for construction materials and equipment. However, our study observed relatively low usage of CD and EDI by stakeholders in the Nigerian building industry. This is contrary to the situation in the UK, where Eadie et al. ${ }^{15}$ reported that a majority of their procurement activities were done electronically on write-once CD. In the $\mathrm{USA}^{9}$ and $\mathrm{Australia}^{48}$, EDI was used for communication and exchange of procurement information and data in the construction industry. In addition, there was low utilisation of cloud-based systems such as Dropbox, Microsoft Share Point, and Web 2.0 technologies (interactive websites) to support the execution of the five building procurement tasks investigated in this study.

Indeed, our survey data clearly show that the most frequently used e-procurement technologies, tools, and applications in the Nigerian building industry are e-mails and static websites, while the use of Web 2.0 
technologies (e.g. interactive websites) and cloud-based applications are minimal. This suggests that the industry has yet to maximise the benefits of e-procurement in the procurement of building projects in an efficient and effective manner. This situation is similar to that in Australia, as previously highlighted by Zunk et al. ${ }^{48}$ The findings in the current study imply that the Nigerian building industry needs to further develop its e-procurement adoption initiates by engaging the use of interactive and integrative e-procurement technologies that promote collaboration, coordination, and integration of procurement tasks in order to enjoy the full benefits of e-procurement in addressing the huge building infrastructure supply deficit. This calls for investment and awareness on the benefits of these categories of e-procurement technology.

Third, the study also found that five organisational factors contributed significantly to influencing the decision by the organizations to use the identified e-procurement technologies and tools by stakeholders in the Nigerian building industry. In order of their contribution, the factors that influenced the decision to engage in e-procurement activities are e-notification, e-exchange, e-submission, e-sourcing and e-payment in the category of the organization with a beta value of 0.308 . This finding can be linked to the suggestion by Othman ${ }^{38}$ that the type of decision-making process was a key factor influencing innovation adoption. This assertion is based on the notion that one of the factors that determine the type of decision-making process in an organisation is the type of organisation. Arguably, this result appears to be similar to the finding on the influence of the type of organisation in e-procurement adoption amongst architecture, construction, and engineering firms in Singapore ${ }^{18}$ and contracting firms in the UK as reported by Eadie et al. ${ }^{15}$ and stakeholders in the South African construction industry. ${ }^{8}$ Next is the top management support. This specific finding seems to provide support to the earlier studies ${ }^{18,16,51}$, indicating that top management support was one the key factors influencing organisations' decision to adopt e-procurement. There is also the desire of the organizations' top management to align with the global trend in e-procurement use, which also showed significant influence on the decision to adopt e-procurement. This factor can be linked to the organisational policy on e-procurement use as previous highlighted by Patel et al. ${ }^{51}$ Such a policy is usually a product of top managements' attitude towards the global trend in e-procurement use in the construction industry.

Furthermore, the emergence of the financial base and availability of IT-savvy staff in the organisations as two of the key factors influencing e-procurement adoption in the Nigerian building industry did not come as a surprise. This is because previous studies ${ }^{12,50,51}$ have identified the financial 
and human resource base as one of the key factors that influence e-procurement adoption by organisations. Contrary to the finding by Eadie et al. $^{15}$ that the size of organisations influences their adoption of e-procurement, the current study shows that the size of the organisations did not make any signification contribution to the decision to use e-procurement. This difference in result might be because, whereas the study by Eadie et al. ${ }^{15}$ focused only on contracting firms in the UK, the current study is a survey of key stakeholders in the Nigerian building industry.

The findings on the influence of organisational factors are emphatic in showing that the key organisational factors to be considered by construction entities that might wish to adopt e-procurement are top management and support organizations' attitude toward the current global trend in the use of e-procurement in construction, the availability of finance resources, and IT-savvy staff. This implies that, in the context of the Nigerian building industry, only private sector organisations whose top management supports the use of e-procurement have favourable attitudes towards the global trend on e-procurement use in construction, a good financial resource base, and IT-savvy staff would most likely adopt e-procurement.

\section{CONCLUSIONS}

This study examined e-procurement use in the Nigerian building industry using data derived from a survey of industry stakeholders. From the findings, the following conclusions are made. The first conclusion is that the actual users of e-procurement are consulting and contracting firms as well as professionals in quantity surveying and construction/project management practices in the building industry in Nigeria. The second conclusion is that there is extensive use of Internet-supported technologies, mainly e-mails and static websites, to support the execution of construction procurement activities related to e-announcement/notification, e-submission and e-sourcing in the Nigerian building industry. Last but not the least, the three most important organisational factors that influenced the decision by organisations to use e-procurement in the Nigerian building industry are the type of organization, top management support, and organisations' attitude towards the global trend in e-procurement use.

\section{REFERENCES}

[1] M. Berisha-Namani, Information technology, internet and marketing. International Journal of Electronic Commerce Studies, 4(1), p103-110, 2013. http://dx.doi.org/10.7903/ijecs.1116.

[2] T. Kobayashi, H. Okada, N. Cooharojananone, V. Bracamonte, and T. 
Suzuki, How can electronic commerce in developing countries attract users from developed countries? A comparative study of Thailand and Japan. International Journal of Electronic Commerce Studies, 4(2), p159-184, 2013. http://dx.doi.org/10.7903/ijecs.1105.

[3] T. M. Cherian, and L. A. Kumaran, E-business in construction industry: Opportunities and challenges. Indian Journal of Science and Technology, 9(32), p1-6, 2016. http://dx.doi.org/10.17485/ijst/2016/v9i32/98655.

[4] P. O. Bausa, S. Kourtidis, K. Liljemo, N. Loozen, F .J. Rodrigues, and M. Snaprud, E-procurement Golden Book of Good Practice, 2013. Retrieved on May 15, 2014 from www.pwc.be.

[5] International Organization for Standard, Construction Procurement-Part 1: Process, Methods and Procedures, ISO, Geneva, Switzerland, 2010.

[6] N. Hashim, I. Said, and N.H. Idris, Exploring e-procurement value for construction companies in Malaysia. Procedia Technology, 9, p836-845, 2013.

[7] Y. Ren, M. J. Skibniewski, and S. Jiang, Building information modeling integrated with electronic commerce material procurement and supplier performance management system. Journal of Civil Engineering and Management, 18(5), p642-654, 2012. https://doi.org/10.3846/13923730.2012.719835.

[8] E. O. Ibem, and S. Laryea , E- procurement use in the South African construction industry. Journal of Information Technology in Construction, 20, p364-384, 2015.

[9] R. A. Issa, I. Flood, and G. Caglasin, Survey of e-business implementation in the US construction industry. Journal of Information Technology in Construction, 8, p15-28, 2003.

[10] J. H. Rankin, Y. Chen, and A. J. Christian, E-procurement in the Atlantic Canadian AE industry. Journal of Information Technology in Construction, 11, p75-87, 2006.

[11] P. X. W. Zuo, and Y. Seo, Effective applications of e-commerce technologies in construction supply chain: Current practice and future improvement. Journal of Information Technology in Construction, 11, p127-147, 2006.

[12] R. Eadie, S. Perera, G. Heaney, and J. Carlisle, Drivers and barriers to public sector e-procurement within Northern Ireland's construction industry. Journal of Information Technology in Construction, 12, p103-120, 2007.

[13] R. Eadie, S. Perera, and G. Heaney, A cross -discipline comparison of rankings for e-procurement drivers and barriers within UK construction organizations. Journal of Information Technology in Construction, 15, p217-23, 2010a. 
[14] R. Eadie, S. Perera, and G. Heaney, Identification of e-procurement drivers and barriers for UK construction organizations and ranking of these from the perspective of quantity surveyors. Journal of Information Technology in Construction, 12, p103-120, $2010 \mathrm{~b}$.

[15] R. Eadie, S. Perera, and G. Heaney, Analysis of the use of e-procurement in the public and private sectors of the UK construction industry. Journal of Information Technology in Construction, 16 p669-686, 2011.

[16] U. Isikdag, J. Underwood, V. Ezcan, and S. Arslan, Barriers to e-Procurement in Turkish AEC Industry. Proceedings of the CIB W78-W102 2011: International Conference, Sophia Antipolis, France, October 26-18, 2011.

[17] S. Laryea, and E. O. Ibem, Barriers and prospects of e-procurement uptake in the South African construction industry. In Talukhaba, A.A. (ed), Proceedings of the 7th Annual Quantity Surveying Research Conference (p22-23), CSIR International Convention Centre, Pretoria, South Africa, 2014.

[18] T. S. H. Teo, S. Lin and K. Lai, Adopters and non-adopters of e-Procurement in Singapore: An empirical study. Omega, 37(5), p972-987, 2009. https://doi.org/10.1016/j.omega.2008.11.001.

[19] N. M. Daud, N. Mohammad, A. E. Azmi, and I. S. Mohamed, Factors influencing the usage of e-Procurement among contractor companies in Malaysia. Business and Management Quarterly Review, 4(3\&4), p62-80, 2013.

[20] A. Grilo, R. Jardim-Goncalves, Challenging electronic procurement in the AEC sector: A BIM- based integrated perspective. Automation in Construction, 20(2), p107-114, 2011. https://doi.org/10.1016/j.autcon.2010.09.008.

[21] Y. Yu, H. Yu, H. Itoga, and T. Lin, Decision-making Factors for Effective Industrial e-Procurement. Technology in Society, 30(2), p163-169, 2008. https://doi.org/10.1016/j.techsoc.2007.12.004.

[22] A. Shukla, M. A. Khan, and M. Shah, Literature review of adoption of E procurement practices by construction industries. AIMA Journal of Management \& Research, 10 (2/4), p1-25, 2016.

[23] E. O. Ibem, E. B. Aduwo, P. Tunji-Olayeni, E. A. Ayo-Vaughan, and U. O. Uwakonye, Factors influencing e-procurement adoption in the Nigerian building industry. Construction Economics and Building, 16 (4), p54-67, 2016. http://dx.doi.org/10.5130/AJCEB.v16i4.4984.

[24] Y. Rezgui, I. E. Wilson, L. Damodaran, W. Olphert, and M. Shilboum, ICT adoption in the construction sector: Education and training issues 2004. Retrieved on March 6, 2014, from: http://e-pub.uni-weimar.de/volltexte/.

[25] A. Al-Moala, and D. Li, Organisational issues with electronic 
government procurement: A case of the UAE, The Electronic Journal on Information Systems in Developing Countries. 41(3), p1-18, 2010. https://doi.org/10.1002/j.1681-4835.2010.tb00292.x

[26] Q. D. Tran, and D. C Huang, E-procurement institutionalization in construction industry in developing countries: A model and instrument. Wseas Transactions on Computers, 13, p152-176, 2014.

[27] K. S. Eei, W. Husain, and N. Mustaffa, Survey on benefits and barriers of e-procurement: Malaysian SMEs perspective. International Journal on Advanced Science Engineering Information Technology, 2(6), p14-19, 2012. http://dx.doi.org/10.18517/ijaseit.2.6.238.

[28] O. S. Oyediran, and A. A. Akintola, A survey of the state of the art of e-tendering in Nigeria. Journal of Information Technology in Construction, 16, p557-576, 2011.

[29] E. B. Aduwo, E. O. Ibem, P. Tunji-Olayeni, U. O. Uwakonye, and E. K, Ayo-Vaughan, Barriers to the uptake of e-procurement in the Nigerian building industry. International Journal of Applied Theoretical and Applied Information Technology, 89(1),p133-147, 2016.

[30] S. P. Williams, and C. Hardy, Public, e-procurement as socio-technical change. Strategic Change. 14, p273-281, 2005. http://dx.doi.org/10.1002/jsc.728.

[31] P. X. W. Zuo, and Y. Seo, Effective applications of e-commerce technologies in construction supply chain: Current practice and future improvement. Journal of Information Technology in Construction, 11, p127-147, 2006.

[32] Y. Wanga, J. Yanga, Q. Shen, The application of electronic commerce and information integration in the construction industry. International Journal of Project Management, 25(2), p158-163, 2007. https://doi.org/10.1016/j.ijproman.2006.09.008

[33] N. M. Daud, N. Mohammad, A. E. Azmi, and I. S. Mohamed, Factors influencing the usage of e-Procurement among contractor companies in Malaysia. Business and Management Quarterly Review, 4(3\&4), p62-80, 2013.

[34] E. Rogers, Diffusion of Innovations (5th ed.). New York: Free Press, 2003.

[35] L. Tornatzky, and M. Fleischer, The Process of Technology Innovation. Lexington, MA: Lexington Books, 1990.

[36] C. Tatum, Organizing to increase innovation in construction firms. Journal of Construction Engineering and Management, 115(4), p602-617,1989.

http://dx.doi.org/10.1061/(ASCE)0733-9364(1989)115:4(602)

[37] M. F. I. Othman, Barriers to the Adoption of Formal IT Governance Practice: A Malaysian Case. Unpublished PhD thesis Submitted to the School of Information Systems Science and Engineering Faculty 
Queensland University of Technology Brisbane, Australia, 2016.

[38] A. Gunasekaran, and E.W.T Ngai, Adoption of e-Procurement in Hong Kong: An empirical research, International Journal of Production Economics, 113(1), p159-175, 2008. http://dx.doi.org/10.1016/j.ijpe.2007.04.012

[39] S. Farzin, and H. Nezhad, E-procurement, the golden key to optimizing the supply chains system. International Journal of Economics and Management Engineering, 4(6), p449-456, 2010.

[40] J. A. Obel, I. O. Abiero, and A. Njeru, Organisational factors affecting the adoption of e-procurement system in the county governments: A case of Nairobi city county. International Journal of Science and Research, 5(10), p813-819, 2016.

[41] A. A. Costa, and A. Grilo, BIM-based e-procurement: An innovative approach to construction e-procurement. The Scientific World Journal, 2015. Retrieved on June 20, 2016, form http://dx.doi.org/10.1155/2015/905390.

[42] J. Bilali, and H. Bwisa, Factors influencing the adoption of e-procurement: A case of Garissa county government. The Strategic Journal of Business \& Change Management, 35, p662-682, 2015.

[43] N. A. Bakar, K. Peszynski, N. Azizan, V. Pandiyan, and K. Sundram, Abridgment of traditional procurement and e-procurement: Definitions, tools and benefits. Journal of Emerging Economies and Islamic Research, 4(1), p1-18, 2016.

[44] S. Laryea, and E. O. Ibem, Patterns of technological innovation in the use of e- procurement in construction. Journal of Information Technology in Construction, 19, p104-125, 2014.

[45] A. R. S. Ahamed, G. Karunasena, S. Jayasena, I. Seneviratne, and S. Perera, Exploring the status of e-procurement : A case of the construction industry in Sri-Lanka. In C. J. Anumba, N. M. Bouchlaghem, J. I. Messner, and M. K. Parfitt (Eds.), Proceedings of the 6th International Conference on Innovation in Architecture, Engineering and Construction (AEC), The Nittany Lion, Pennsylvania State University, USA, June 9-11, 2010, p456-465. Retrieved on December 12, 2016, from http://www.engr.psu.edu/ae/AEC2010/index.asp.

[46] D. C. Huang, Q. D. Tran, T. Q. T. Nguyen, and A. Nazir, Initial adoption vs. institutionalization of e-procurement in construction firms: The role of government in developing countries. International Journal of Enterprise Information Systems. 10(4), p1-21, 2014. http://dx.doi.org/10.4018/ijeis.2014100101.

[47] B. M. Zunk, M. J. Marchner, I. Uitz, C. Lerch, and H. Schiele, The role of e-procurement in the Austrian construction industry: Adoption rate, benefits and barriers. International Journal of Industrial Engineering 
and Management, 5(1), p13-21, 2014.

[48] B. H. Sholanke, and J. A. Fapohunda, Impacts of E-commerce on Construction Materials Procurement for Sustainable Construction. Sustainable Technologies (WCST), 2015 World Congress on 14-16 December, 2015. Retrieved on March 5, 2017, from http://ieeexplore.ieee.org/document/7415120/?reload=true.

[49] E. Ng, Making strategic decisions on B2B e-commerce models: An empirical study on Australian agribusinesses. International Journal of Electronic Commerce Studies, 4(1), p1-20, 2013. http://dx.doi.org/10.7903/ijecs.995.

[50] P. Patel, D. Satrndraku, R. Khajuria, A study to identify factors that affect e-procurement implementation. International Journal of Science Technology \& Engineering, 2(9), p264-268, 2016.

[51] S. L. Shrestha, Categorical regression models with optimal scaling for predicting indoor air pollution concentrations inside kitchens in Nepalese households. Nepal Journal of Science and Technology, 10, p205-211, 2009. http://dx.doi.org/10.3126/njst.v10i0.2962. 


\section{APPENDIX}

Covenant University, Km 10 Idiroko Road, Canaan Land, Ota, Ogun State Nigeria

\section{Questionnaire}

Dear Respondent,

The Built Environment Research Cluster of the School of Environmental Sciences, Covenant University, Ota, would like to invite you to take part in a research on the use of electronic procurement in the Nigerian construction industry. E-procurement refers to the use of electronic communications to buy services, goods and works or conduct tendering for construction works. The research seeks to ascertain the state of e-procurement use in the construction industry; and how the use of e-procurement technologies can be diffused and its benefits maximised in the Nigerian construction sector. All information provided will be treated with strict anonymity and used only for academic purposes.

Thank you for engaging with us in this research.

\section{Please tick $(\sqrt{ })$ as appropriate}

1. Please indicate your role in the construction industry; Architect ( ) Builder ( ) Engineer

( ) Contractor ( ) Construction/ Project Manager ( ) Quantity Surveyor ( )

Procurement/ Supply Chain Manger ( ） Others, please specify---------------------

2. In which of the following categories of organizations are you employed? Consulting

Firm ( ) Contractor ( )

Client organization ( ) Government Ministry/Parasatals/Institution ( ）

Others, please specify

3. Your construction procurement experiences are mostly in the Public Sector ( )

Private Sector ( ) Both Public and Private Sectors ( )?

4. What is the staff strength of your organization? Below 20 persons ( ) 20-50 Persons

( ) 51-100 persons ( ) More than 100 persons ( ) 
5. How many years have your organization been in business? Below 5years ( ) 6-10years $(\quad) 10$ years $+(\quad)$

6. How many offices do you have in Nigeria? $1 \quad(\quad) 2 \quad(\quad) 3 \quad(\quad)$ More than 3 offices ( )

7. What is the range of your organization's annual turnover? Less than $\$ 100$ million ( ) $\$ 100 \mathrm{~m}$ - $\$ 500$ Million（） $\$ 600 \mathrm{~m}$ - $\$ 1$ billion ( ) Over $\$ 1$ billion ( )

8. Are you aware of the use of electronic procurement in construction? Yes ( ) No ( )

9. Which of these e-Procurement service providers does your organization subscribe to? Ariba ( ) Oracle ( ) Alibaba ( ); Others, Please specify-

10. How did you hear about e-Procurement in construction? Professionals Associations ( ) Mass Media ( ) Workshop/Conferences ( ) Vendors of e-Procurement technologies ( ) Business Associates ( )

11. How long have you been using e-Procurement in your organization? Less than 1 year ( ) 1-5years ( ) 6-10years ( ) More than 10years ( )

12. Have your oraganisation participated in construction project (s) that involved the use of e-procurement packages?

Yes ( ) No ( )

\begin{tabular}{|l|l|l|l|l|}
\hline & $\begin{array}{l}\text { Please indicate how often you use these technologies and tools } \\
\text { to carry out the following procurement activities. ( Where 1=Never } \\
\text { used; 2=Used Sometimes; 3= Used Always) }\end{array}$ & $\mathbf{2}$ & $\mathbf{3}$ \\
\hline 1 & $\begin{array}{l}\text { Obtain project briefs from Clients/ Give out project briefs to } \\
\text { consultants }\end{array}$ & & \\
\hline a & E-mail Attachment & & \\
\hline b & Internet-Supported Faxing & & \\
\hline c & Voice of Internet Protocol (e.g. Skype) & & & \\
\hline 2 & Prepare construction drawings and documents & & \\
\hline a & Revit Architecture & & & \\
\hline b & ArchiCAD & & & \\
\hline c & Sketch up & & \\
\hline d & AUTOCAD & & \\
\hline
\end{tabular}




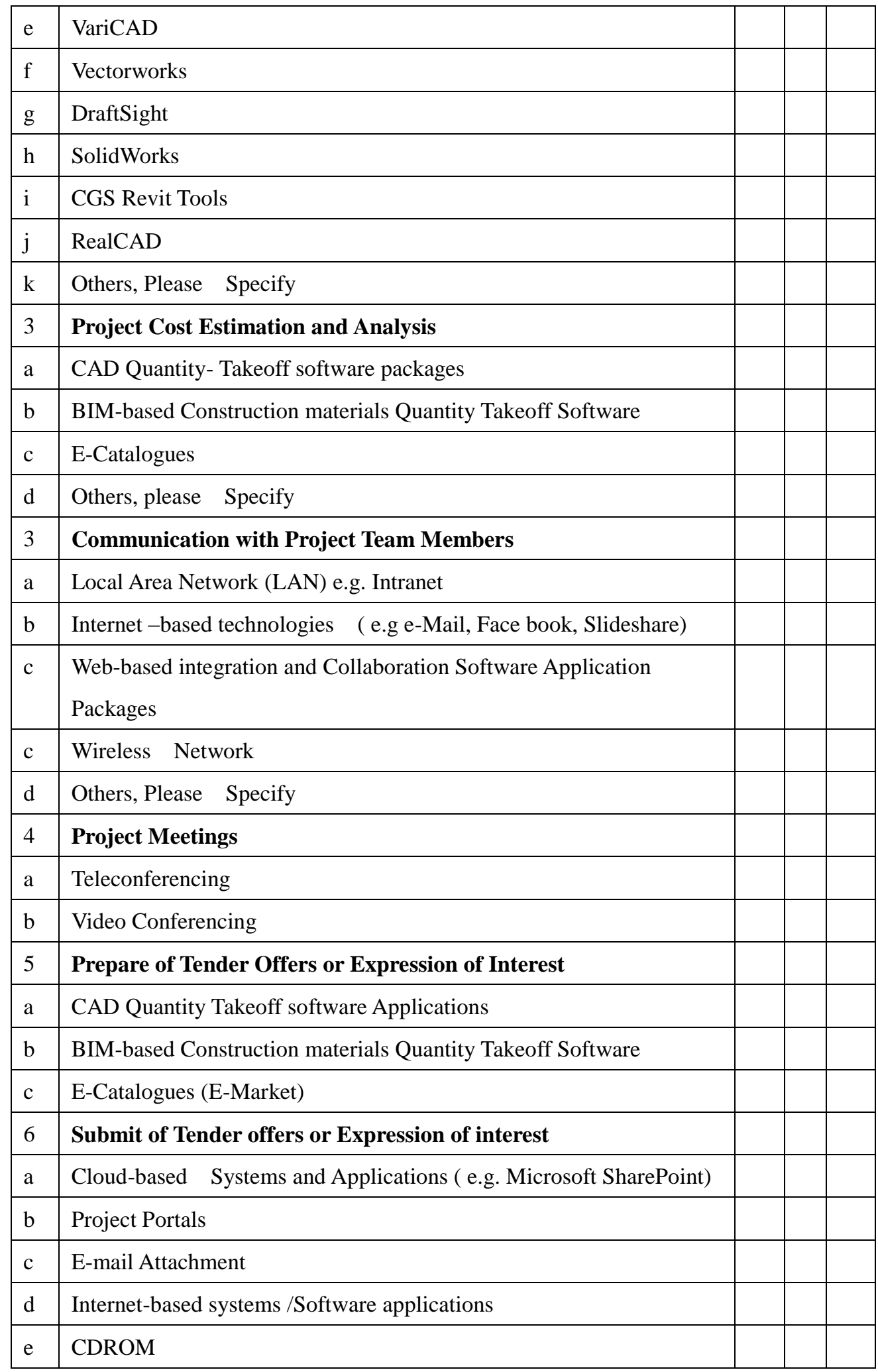




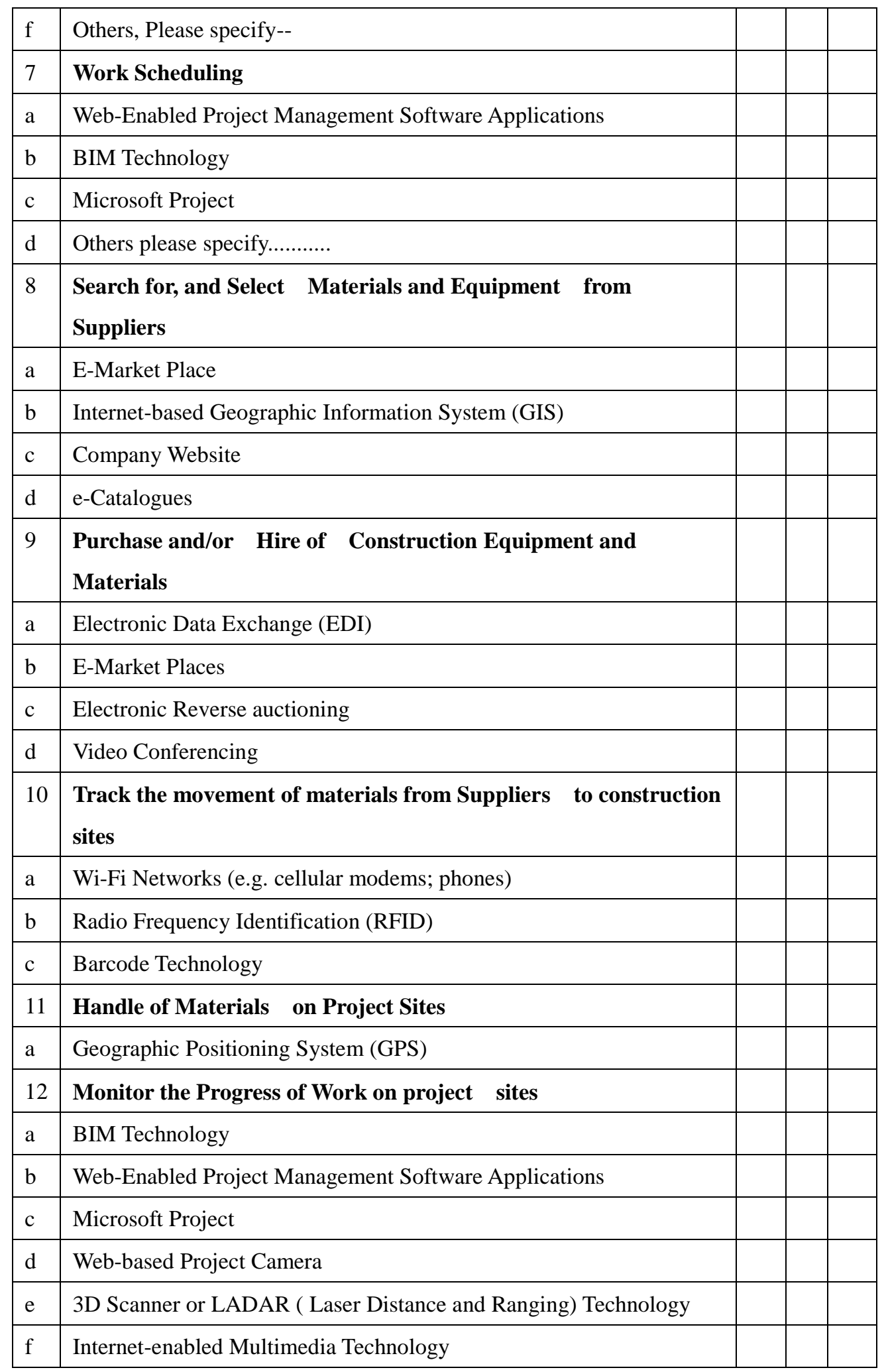




\begin{tabular}{|l|l|l|l|l|}
\hline 13 & Track Project Cost and Scheduling & & & \\
\hline b & Radio Frequency Identification (RFID) & & \\
\hline c & BIM Technology & & \\
\hline 14 & $\begin{array}{l}\text { Make/ Receive of Payment for construction goods, works and } \\
\text { services }\end{array}$ & & \\
\hline a & Credit Card & & & \\
\hline b & Electronic fund Transfer (EFT) & & \\
\hline c & Others, Please Specify & & \\
\hline
\end{tabular}

\section{B: Factors influencing the use of e-Procurement in Construction}

\begin{tabular}{|c|c|c|c|c|c|c|}
\hline \multicolumn{7}{|c|}{$\begin{array}{l}\text { Please rate the following in the order of their importance on the de } \\
\text { organization to use e-Procurement in construction s [ } 1=\text { "Not Import } \\
\text { Important"; } 3=\text { "Undecided" } 4=\text { "Important" } 5=\text { "Most Important"] }\end{array}$} \\
\hline & & 1 & 2 & 3 & 4 & 5 \\
\hline 1 & Availability of e-Procurement Packages & & & & & \\
\hline 2 & The cost of acquiring and operating the packages & & & & & \\
\hline 3 & $\begin{array}{l}\text { The extent to which e-Procurement technologies and tools } \\
\text { are easy to use }\end{array}$ & & & & & \\
\hline 4 & Availability of IT staff/manpower in my organization & & & & & \\
\hline 5 & $\begin{array}{l}\text { The compatibility of e-Procurement with our existing } \\
\text { procurement processes }\end{array}$ & & & & & \\
\hline 6 & $\begin{array}{l}\text { Result of the initial attempt to use e-Procurement in my } \\
\text { organization }\end{array}$ & & & & & \\
\hline 7 & The number of existing users amongst my business partners & & & & & \\
\hline 8 & $\begin{array}{l}\text { The decision by our clients/service providers to use } \\
\text { e-Procurement }\end{array}$ & & & & & \\
\hline 9 & The desire to align with the global trend in e-Procurement use & & & & & \\
\hline 10 & $\begin{array}{l}\text { What early users said about e-Procurement technologies and } \\
\text { tools }\end{array}$ & & & & & \\
\hline 11 & $\begin{array}{l}\text { The geographical spread of the business activities of my } \\
\text { organization }\end{array}$ & & & & & \\
\hline 12 & Scope of the operational activities of my organization & & & & & \\
\hline
\end{tabular}




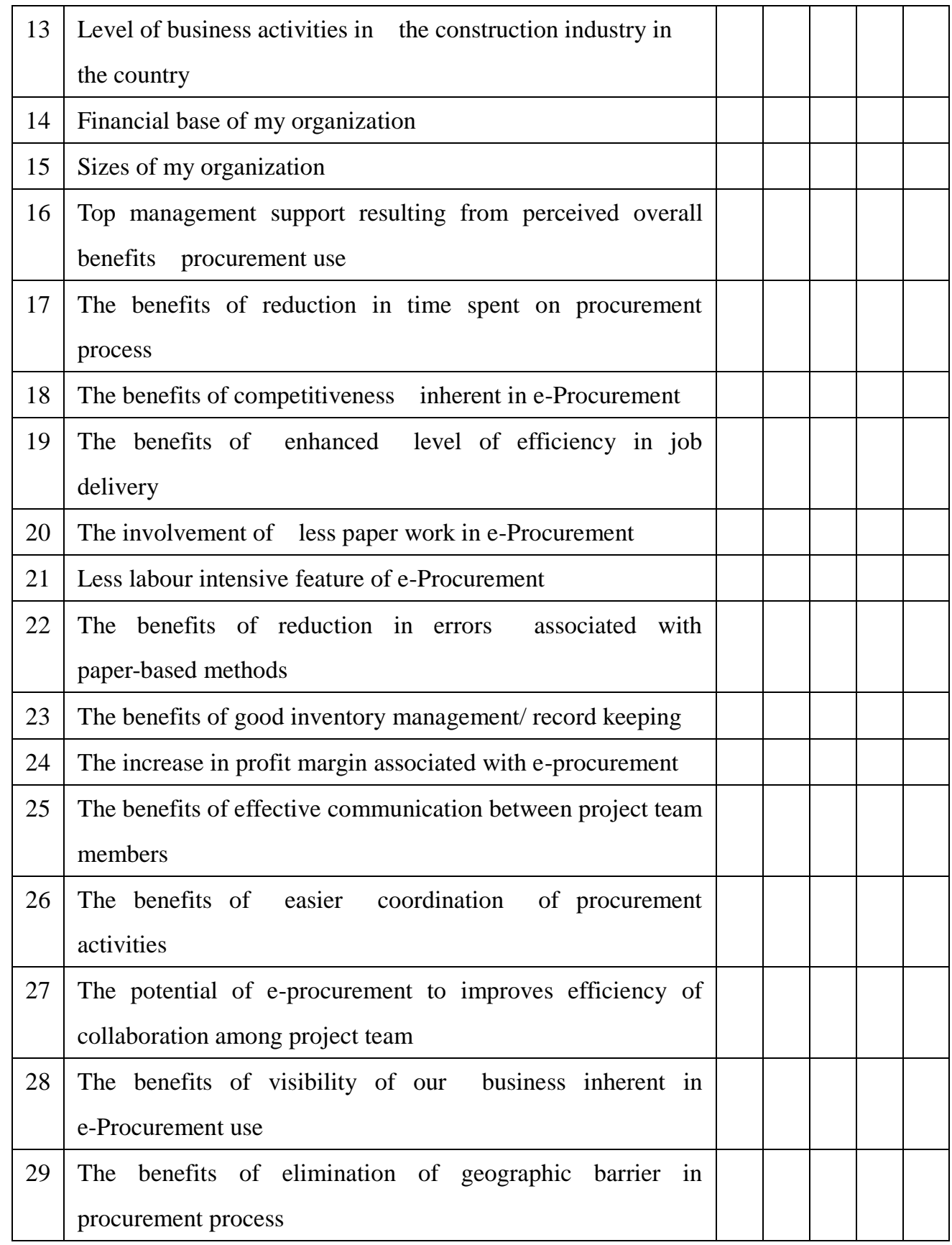

C: Factors Adversely Affecting the Maximization of the Benefits of e-Procurement in Construction

Please rate the following factors in order of their adverse impact on e-Procurement use in construction [ 1 = "Has No Significant Effect"; $\mathbf{2}$ = "Has Very Little Effect"; 3 = 
Egidario B. Aduwo, Eziyi O. Ibem, Emmanuel A. Ayo-Vaughan, Uwakonye O. 253 Uwakonye, and James D. Owolabi

\begin{tabular}{|c|c|c|c|c|c|c|}
\hline \multicolumn{7}{|c|}{ "Undecided" $\mathbf{4}=$ " Has Significant Effect" 5 = "Has The Most Significant Effect"] } \\
\hline & & 1 & 2 & 3 & 4 & 5 \\
\hline 1 & $\begin{array}{l}\text { The benefits of using e-Procurement in construction are not } \\
\text { very clear }\end{array}$ & & & & & \\
\hline 2 & $\begin{array}{l}\text { Technical challenges associated with the transition from } \\
\text { paper-based method to e-Procurement }\end{array}$ & & & & & \\
\hline 3 & $\begin{array}{l}\text { Lack of widely accepted e-Procurement software solution in } \\
\text { construction }\end{array}$ & & & & & \\
\hline 4 & $\begin{array}{l}\text { Lack of technical expertise to handle e-Procurement } \\
\text { technologies }\end{array}$ & & & & & \\
\hline 5 & $\begin{array}{l}\text { The complicated nature and process involved in } \\
\text { e-Procurement use }\end{array}$ & & & & & \\
\hline 6 & Unreliable power supply situation in Nigeria & & & & & \\
\hline 7 & Poor Internet and ICT Infrastructure in Nigeria & & & & & \\
\hline 8 & $\begin{array}{l}\text { High cost of investment in e-Procurement Technologies and } \\
\text { Tools }\end{array}$ & & & & & \\
\hline 9 & Lack of interoperability of e-Procurement software packages & & & & & \\
\hline 10 & $\begin{array}{l}\text { Lack of uniform standards in the use of e-Procurement } \\
\text { packages }\end{array}$ & & & & & \\
\hline 11 & Safety and Security issues in e-Procurement transactions & & & & & \\
\hline 12 & Lack of confidentially in e-Procurement transactions & & & & & \\
\hline 13 & Delays in the transmission of data and information & & & & & \\
\hline 14 & Concerns over the legality of electronic contracts & & & & & \\
\hline 15 & Lack of a National policy on e-Procurement in Nigeria & & & & & \\
\hline 16 & $\begin{array}{l}\text { Lack of forum to exchange ideas on the use of } \\
\text { e-Procurement }\end{array}$ & & & & & \\
\hline 17 & $\begin{array}{l}\text { Inadequate government support for e-Procurement in } \\
\text { construction }\end{array}$ & & & & & \\
\hline 18 & $\begin{array}{l}\text { Lack of universal format and standard in which construction } \\
\text { materials are described, displayed and specified }\end{array}$ & & & & & \\
\hline 19 & $\begin{array}{l}\text { General resistance to change by people in the construction } \\
\text { industry }\end{array}$ & & & & & \\
\hline
\end{tabular}




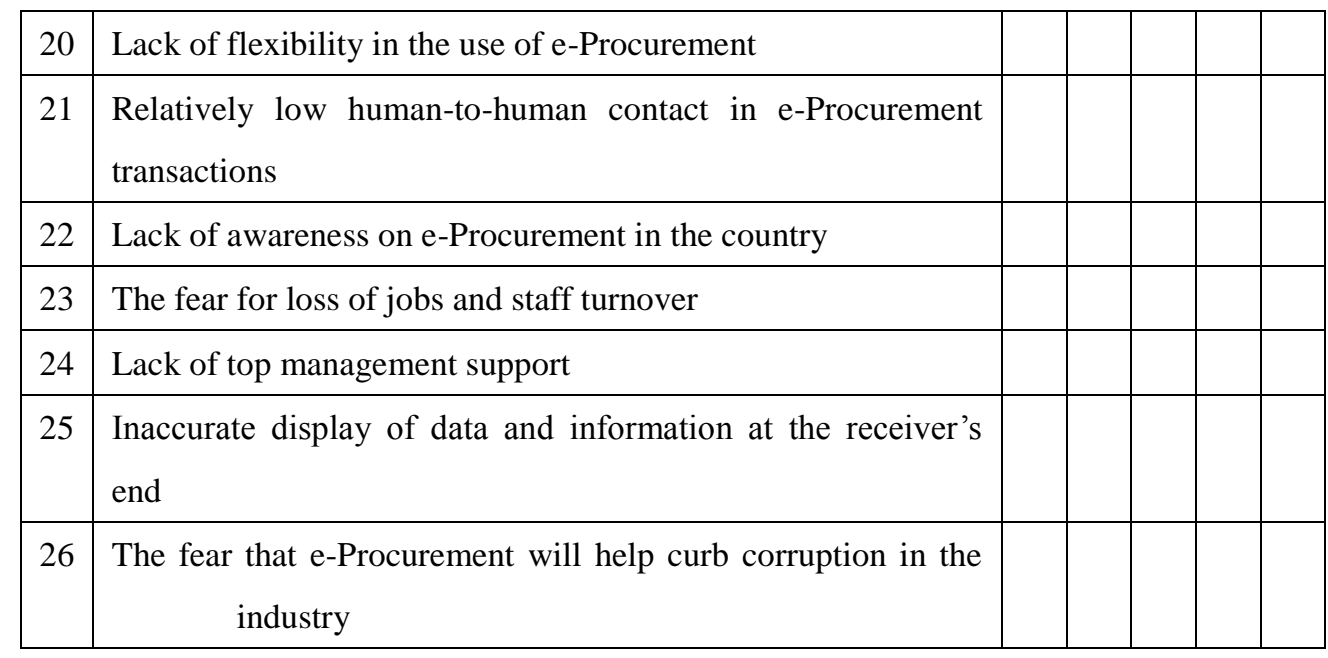

Please, kindly suggest how the benefits of e-Procurement in construction can be maximised in the Nigerian construction industry.

If you would like to engage with us further in research, please provide us with your contact details below

Name of your Organization:

Location:-

E-Mail Address: 